\title{
The Strong Correlation Between ADAM33 Expression and Airway Inflammation in Chronic Obstructive Pulmonary Disease and Candidate for Biomarker and Treatment of COPD
}

\section{Muhammad Fachri}

Universitas Muhammadiyah Jakarta

Mochammad Hatta ( $\square$ hattaram@yahoo.com )

Hasanuddin University https://orcid.org/0000-0002-8456-4203

Muhammad Nasrum Massi

Universitas Hasanuddin Fakultas Kedokteran

\section{Arif Santoso}

Universitas Hasanuddin Fakultas Kedokteran

\section{Tri Ariguntar Wikanningtyas}

Universitas Muhammadiyah Jakarta

\section{Ressy Dwiyanti}

Tadulako University: Universitas Tadulako

Ade Rifka Junita

Universitas Hasanuddin Fakultas Kedokteran

Muhammad Reza Primaguna

Universitas Hasanuddin Fakultas Kedokteran

\section{Muhammad Sabir}

Universitas Tadulako Fakultas Kedokteran dan IImu Kesehatan

\section{Research}

Keywords: COPD patients, ADAM33, mRNA expression, soluble levels, inflammatory reactions

Posted Date: June 22nd, 2021

DOl: https://doi.org/10.21203/rs.3.rs-626061/v1

License: (1) This work is licensed under a Creative Commons Attribution 4.0 International License. Read Full License 


\section{Abstract}

Background: Airway inflammation in patients with chronic obstructive pulmonary disease (COPD) is an amplified response of the normal immune system that occurs as a result of chronic irritation by toxic substances, such as cigarette smoke. This leads to the characteristic pathological changes in the inflammatory cells of COPD patients. ADAM33 has been reported to be involved in the pathogenesis of COPD in East Asia by affecting airway inflammation and other immune responses. The aim of this study was to determine the potential role of $A D A M 33$ (mRNA and soluble levels) as a biomarker of inflammation in COPD patients.

Methods: This is a case control study using consecutive sampling. The COPD case and control (nonCOPD) groups comprised 37 and 29 patients, respectively. We used univariate analysis to assess differences in the parameters between the groups and bivariate analysis to non-parametrically compare these parameters between the two groups.

Results: We observed significantly higher mRNA levels of $A D A M 33$ in the COPD patients $(10.39 \pm 1.76)$ as compared to that in the non-COPD individuals $(6.93 \pm 0.39 ; p<0.001)$. The levels of soluble ADAM33 were also significantly higher in the COPD patients $(2.188 \pm 1.142 \mathrm{ng} / \mathrm{ml})$ compared to the non-COPD individuals $(0.487 \pm 0.105 \mathrm{ng} / \mathrm{ml} ; \mathrm{p}<0.001)$.

Conclusion: The mRNA and soluble ADAM33 levels were significantly different in COPD patients compared to those in the parameter-matched non-COPD individuals. Thus, ADAM33 is a potential biomarker and treatment for inflammation in COPD patients.

\section{Background}

Chronic obstructive pulmonary disease (COPD) is a chronic lung disease that manifests with persistent respiratory symptoms and limited airflow. Exposure to harmful particles or toxic gases results in abnormalities in the airways or alveoli that lead to COPD [1,2]. Airway inflammation in COPD patients is an amplified inflammatory response to chronic irritation, such as cigarette smoke. Among several studies, Wang et al. reported the involvement of $A D A M 33$ in the pathogenesis of COPD in the East Asian population: $A D A M 33$ regulates airway inflammation and immune response in COPD patients. Laxmi et al. showed a significant correlation between the genetic polymorphisms in ADAM33 S1-A/G and S2-C/G and pathophysiology of COPD in the South Indian population. The inflammatory response associated with COPD includes changes in pro-inflammatory or anti-inflammatory cytokines and occurs predominantly in the presence of $A D A M 33$ polymorphisms $[3,4,5]$.

Kim et al. demonstrated that active vitamin $\mathrm{D}_{3}$ regulates vascular endothelial growth factor (VEGF) that stimulates $A D A M 33$ expression and proliferation in smooth muscle cells; this can be used to influence the treatment outcome in patients with asthma [6]. Zhang et al. showed that lipopolysaccharide decreases the proliferation and functionality of human primary lung fibroblasts (important targets in patients with COPD) [7]. Increased mRNA and soluble levels of ADAM33 can serve as bridges for these cytokines that 
results in damage to the matrix. In this study, we investigated the role of $A D A M 33$ (mRNA and soluble form) in matrix damage as part of the pathomechanism involved in COPD.

\section{Methods}

\section{Study design and population}

This is a case control study using consecutive sampling. The COPD case group included 37 patients, and the control group comprised 29 non-COPD patients. We used IBM SPSS Statistics version 23 in this study. Univariate analysis was used to evaluate the differences in the parameters between groups. Bivariate analysis was performed to compare these parameters between two groups by non-parametric statistics.

\section{ADAM33 mRNA levels}

The mRNA levels of $A D A M 33$ were determined by extracting nucleic acids using the method described by Boom et al [8]. Briefly, $100 \mu \mathrm{l}$ of peripheral blood was incubated with $900 \mu \mathrm{l}$ of a solution consisting of guanidium thiocyanate. Subsequently, a $20-\mu$ l suspension consisting of $50 \mathrm{ml}$ of $\mathrm{H}_{2} \mathrm{O}$ and $500 \mu \mathrm{l}$ of $32 \%$ $(\mathrm{w} / \mathrm{v})$ diatom was added to the solution. We removed the supernatant and washed the sediment with a buffer followed by two washes with $1 \mathrm{ml}$ of $70 \%$ ethanol and $1 \mathrm{ml}$ of acetone. The resulting solution was heated in a water bath at $56^{\circ} \mathrm{C}$ for 10 minutes and added to $60 \mu$ of TE buffer consisting of $1 \mathrm{mM}$ EDTA in $10 \mathrm{mM}$ Tris $\mathrm{HCl}(\mathrm{pH} \mathrm{8.0)}$. The supernatant from this mixture was transferred into a fresh tube for nucleic acid isolation and stored at $-80^{\circ} \mathrm{C}$ until subjected to polymerase chain reaction (PCR) $[8,9]$.

The expression profile of target genes was determined using real-time PCR (qRT-PCR). Expression was represented as a ratio of expression of the primary oligonucleotide-specific gene to that of GAPDH (housekeeping gene). ADAM33 mRNA was detected using specific forward (5'-

CAGGAATGCCAGCTATTATC-3') and reverse (5'-GTTTGGTGTGGTTCAAGTTT-3') primers. GAPDH was detected using specific forward (5'-GGCCAAAAGGGTCATCATC-3') and reverse (5'-

GTGATGGCATGGACTGTGG-3') primers. The PCR thermal protocol was as follows: for ADAM33, 38 cycles of $94^{\circ} \mathrm{C}$ for 3 minutes and $54^{\circ} \mathrm{C}$ for 30 seconds; for $G A P D H, 32$ cycles of $94^{\circ} \mathrm{C}$ for 10 seconds and $54^{\circ} \mathrm{C}$ for 30 seconds according to the protocol described by Kim et al. [6]. qRT-PCR was performed with the One-Step SYBR Green qRT-PCR kit optimized for the Real-Time PCR CFX 6400 thermal cycler [6.10]. The total reaction volume was $25 \mu$ l (including experimental RNA) with $12.5 \mu$ l of the $2 \times$ SYBR Green qRT-PCR master mix and " $x$ " $\mu$ of the concentration-optimized primer stocks. Subsequently, " $x$ " $\mu$ l of nuclease-free water along with concentration-optimized final primers, $0.375 \mu \mathrm{l}$ of the reference dye solution from stage 1 (optional), and $1 \mu \mathrm{l}$ of the RT/RNase block enzyme mixture were added to a total reaction volume of 50 $\mu \mathrm{l}$. The reaction was mixed slowly to avoid frothing (without rotating) and " $x$ " $\mu$ l of the RNA-solution mixture was added to individual experimental PCR tubes. The reaction was mixed slowly, briefly centrifuged, and placed in the instrument. The PCR program was run using a real-time PCR machine (CFX Connect system, Bio-Rad Laboratories, Real-Time PCR, 96 wells, 0.1 ml, USA) [6, 9, 10, 11].

\section{Levels of soluble ADAM33}


Levels of soluble ADAM33 were measured by enzyme-linked immunosorbent assay (ELISA). Patient serum samples were prepared using an $A D A M 33$ kit at room temperature. Each sample was analyzed in duplicates to ensure the validity of the data obtained by ELISA. Initially, $100 \mu$ l of the Assay Diluentcontaining protein buffer was added to each well. Next, $100 \mu$ of Standard fluid-containing recombinant human target from a predetermined kit or diluted patient serum samples (1:10) was added to each well. The plate was then incubated for 2 hours at room temperature. The liquid was removed and each well was washed four times with sterile phosphate-buffered saline. Then, $200 \mu$ l of Conjugate buffer with horseradish peroxidase-streptavidin was added to each well, the plate was covered with a plastic lid, and incubated at room temperature for 2 hours. The liquid was removed and plate was washed four times with sterile phosphate-buffered saline. Next, $200 \mu \mathrm{l}$ of Substrate Solution containing TMB was added to each well. The plate was incubated at room temperature for 20 minutes in the dark. After incubation, the reaction was stopped by adding $50 \mu$ of Stop Solution containing $\mathrm{H}_{2} \mathrm{SO}_{4}$ to each well following which levels were measured within 30 minutes using the ELISA Reader 270 (Biomerieux, France) at a wavelength of $450 \mathrm{~nm}$. The target soluble protein concentration was represented in $\mathrm{ng} / \mathrm{ml}[7,12,13,14]$.

\section{Results}

Table 1 shows that there were more males with COPD as compared to females with COPD. Patients with COPD were between 60 and 80 years and were presented to our hospital at an average age of 65.68 years. In comparison, the non-COPD patient controls were between 60 and 81 years with an average age of 67 years. The highest Brinkmann index (3) was found in patients with COPD and non-smokers ( 0 ) in non-COPD control individuals. There were no differences in patient characteristics between groups $(p>$ 0.05). Individuals in both groups were homogeneous based on sex, age, and Brinkmann index.

Table 1

Basic characteristics of COPD patients and non-COPD individuals

\begin{tabular}{|c|c|c|c|c|c|c|}
\hline \multicolumn{2}{|c|}{ Patient characteristics } & \multicolumn{4}{|c|}{ Group } & \multirow[t]{2}{*}{ P-value } \\
\hline & & \multicolumn{2}{|c|}{$\begin{array}{l}\text { COPD (Cases; } n= \\
37)\end{array}$} & \multicolumn{2}{|c|}{$\begin{array}{l}\text { Non-COPD (Control; } n= \\
29 \text { ) }\end{array}$} & \\
\hline \multirow[t]{2}{*}{ Gender } & Male & 33 & $89.19 \%$ & 25 & $86.20 \%$ & \multirow[t]{2}{*}{0.471} \\
\hline & Female & 4 & $10.81 \%$ & 4 & $13.79 \%$ & \\
\hline \multicolumn{2}{|c|}{$\begin{array}{l}\text { Age (years old): Mean (SD)/min- } \\
\max \end{array}$} & \multicolumn{2}{|c|}{$65.68(5.40) / 60-80$} & \multicolumn{2}{|c|}{$67(6.63) / 60-81$} & 0.269 \\
\hline \multirow[t]{4}{*}{ Brinkmann Index } & 0 & \multicolumn{2}{|l|}{5} & \multicolumn{2}{|l|}{17} & 0.973 \\
\hline & 1 & \multicolumn{2}{|l|}{6} & \multicolumn{2}{|l|}{4} & \\
\hline & 2 & \multicolumn{2}{|l|}{9} & \multicolumn{2}{|l|}{6} & \\
\hline & 3 & \multicolumn{2}{|l|}{17} & \multicolumn{2}{|l|}{2} & \\
\hline
\end{tabular}


The mRNA levels of $A D A M 33$ were significantly higher in COPD patients $(10.39 \pm 1.76 ; 95 \%$ confidence interval (Cl): 9.802-10.981) as compared to that in non-COPD individuals $(6.93 \pm 0.39 ; 95 \% \mathrm{Cl}: 6.780-$ 7.079; $p<0.001 ;$ Fig. 1). Similarly, the levels of soluble ADAM33 were also significantly higher in COPD patients $(2.188 \pm 1.142 \mathrm{ng} / \mathrm{ml} ; 95 \% \mathrm{Cl}: 1.807-2.569)$ as compared to that in non-COPD individuals (0.487 \pm 0.105 ng/ml; $95 \%$ Cl: 0.447-0.526; p <0.001; Fig. 2).

\section{Discussion}

The results of this study were in accordance with those reported by Shamara and Fachri (2014): majority of COPD patients were stable (37 people, $86 \%$ ) and 60-69 years (16 people, $37.2 \%$ ). Moreover, 19 stable COPD patients (44.2\%) each manifested with a moderate (2) or severe (3) Brinkmann Index owing to cigarette smoking $[15,16]$. The results of the present study were also in accordance with those seen in COPD patients treated in the Department of Pulmonology, Faculty of Medicine, Persahabatan Hospital, Indonesia: majority of the COPD patients were males (86.2\%) and this can be attributed to the difference in the percentage of male and female smokers [17]. Similarly, Suradi et al. showed that the prevalence of COPD was greater in men than in women comprising a cohort of 49 men and 16 women of which 47 men (72\%) were smokers with acute exacerbation of COPD and positive sputum cultures of Mycobacterium tuberculosis in both DM and without type $2 \operatorname{DM}[18,19,20,21]$. The present study also revealed a role for ADAM33 as a biomarker of inflammation in COPD patients. We found higher levels of ADAM33 mRNA and soluble ADAM33 in COPD patients than that in non-COPD individuals $(p<0.01)$.

Among the numerous studies that have examined the role of ADAM33 mRNA and soluble ADAM33 levels, most are limited to patients with asthma. Foley et al. showed that the mRNA levels of ADAM33 in in vitro cultured primary bronchial epithelial cells from asthma patients were higher than that in donor epithelial cells from asthma patients and cells from normal individuals [22]. Ito et al. compared ADAM33 mRNA levels in smooth muscle cells from asthma patients to that in controls by determining the percentage of the total smooth muscle cells both groups; the ratio of positive/total smooth muscle cells was higher in patients with asthma than that in control individuals. The mRNA levels of ADAM33 were higher in smooth muscle cells from patients with asthma than that in control individuals $(p=0.002)$ [23]. Puxeddu et al. demonstrated an increase in the levels of soluble ADAM33 and its role in angiogenesis; ADAM33 acts as a remodeling gene that functions independent of airway inflammation in airway obstruction through an inflammatory mechanism. Thus, ADAM33 contributes to the pathogenesis of asthma and COPD by interactions between genetic and environmental factors [24]. Taken together, to the best of our knowledge, this is the first report of the mRNA and soluble ADAM33 levels in COPD patients and control individuals.

\section{Conclusion}

COPD patients showed significantly higher mRNA and soluble ADAM33 levels as compared to that in non-COPD individuals. Thus, ADAM33 may serve as an inflammatory biomarker in COPD patients. 


\section{Declarations}

\section{Data Availability}

All data generated or analyzed during this study are included in this published article.

\section{Conflicts of Interest}

The authors declare that there is no conflicts of interest regarding the publication of this paper.

\section{Acknowledgments}

We would like to thank the staff in the Molecular Biology and Immunology Laboratory at the Medical Faculty, Hasanuddin University, Makassar, Indonesia for their technical support for this study. We would like to thank secure.authorservices.springernature.com for English language editing.

\section{Author's contributions}

MF and MH designed the study. MH, MF, RD, ARJ and MRP carried out the laboratory analyses. MF, MH, MNM, ARJ, MRP and TAW, RD and MS reviewed the data, conducted the statistical analyses and interpreted the results. MF, MH, MNN, AS, TAW, RD, ARJ, MRP and MS wrote the first draft of the paper, which all authors critically reviewed. All authors read and approved the final manuscript.

\section{Funding}

The research was funded by BPPDN scholarship [No. 1405.20/E4.4/2015, August 31, 2015]. The funding bodies had no role in the design of this study, collection, analysis, and interpretation of the data, and writing this manuscript.

\section{Availability of data and material}

All data generated or analysed during this study are included in this published article.

\section{Ethics approval and consent to participate}

This research was submitted to the ethics committee of the Faculty of Medicine, Hasanuddin University, Makassar, Indonesia (No. 1006/H4.8.4.5.31/PP36-KOMETIK/2017, November 27, 2017) to obtain approval for ethical studies. Written informed consent was obtained from all participants. 


\section{Consent for publication}

Not applicable.

\section{Competing interests}

The authors declare that they have no competing interests.

\section{References}

1. Global Initiative for Chronic Obstructive Pulmonary Disease, "Diagnosis and assessment. In: Global strategy for diagnosis management and prevention of Chronic Obstructive Lung Disease," NHLBI Publications and Resources, pp. 1-56, 2017.

2. M. Amin, F. Yunus, B. Antariksa, "PPOK (Penyakit Paru Obstruktif Kronik) Diagnosis dan Penatalaksanaan Perhimpunan Dokter Paru Indonesia (PDPI)," Jakarta: Penerbit Universitas Indonesia (UI-Press), pp. 1-91, 2016.

3. X. Wang, W. Li, K. Huang et al., "Genetic variants in ADAM33 are associated with airway inflammation and lung function in COPD," BMC Pulmonary Medicine, vol. 14, pp. 173, 2014.

4. X. Wang, L. Li, J. Xiao et al., "Association of ADAM 33 gene polymorphisms with COPD in a northeastern Chinese population," BMC Medical Genetics, vol. 10, pp. 132, 2009.

5. D. C. Zhou, C. F. Zhou, S. Toloo, T. Shen, S. L. Tong, Q. X. Zhu, "Association of a disintegrin and metalloprotease 33 (ADAM33) gene polymorphisms with the risk of COPD: an updated metaanalysis of 2,644 cases and 4,804 controls," Molecular Biology Reports, vol. 42, no. 2, pp. 409-422, 2015.

6. S. H. Kim, Q. M. Pei, P. Jiang, M. Yang, X. J. Qian, J. B. Liu, “Effect of active vitamin D3 on VEGFinduced ADAM33 expression and proliferation in human airway smooth muscle cells: implications for asthma treatment," Respiratory Research, vol. 18, no. 1, pp. 7, 2017.

7. I. S. Wardani, M. Hatta, R.H. Mubin, A. Bukhari, Mulyanto, M. N. Massi, I. Djaharuddin, B. Bahar, Aminuddin, S. Wahyuni, "Serum vitamin D receptor and High Mobility Group Box-1 (HMGB1) levels in HIV-infected patients with different immunodeficiency status: A cross-sectional study," Annals of Medicine and Surgery, vol 63, no. 2021, pp.102174, 2021. DOI: 10.1016/j.amsu.2021.02.020.

8. L.M.M. Rusyati, M. Hatta, I.G.R.Widiana, M.S. Adiguna, M. Wardana, R. Dwiyanti, R.A. Noviyanti, M. Sabir, Y. Yadi, S. Paramita, A.R. Junita, M.R. Primaguna. "Higher Treg FoxP3 and TGF- $\beta$ mRNA Expression in Type 2 Reaction ENL (Erythema Nodosum Leprosum) Patients in Mycobacterium leprae Infection," The Open Microbiology Journal. vol 14: pp. 304-309. 2020. DOI: 10.2174/1874434602014010304

9. M. Hatta, E. E. Surachmanto, A. A. Islam, S. Wahid S, “Expression of mRNA IL-17F and sIL-17F in atopic asthma patients," BMC Research Notes, vol. 10, no. 1, pp. 202, 2017. 
10. P. Prihantono, M. Hatta, C. Binekada et al., "Ki-67 expression by immunohistochemistry and quantitative real-time polymerase chain reaction as predictor of clinical response to neoadjuvant chemotherapy in locally advanced breast cancer," Journal of Oncology, vol. 2017, pp. 6209849, 2017.

11. R.H. Sirait, M. Hatta M, M. Ramli, A.A. Islam, S.K. Arief, "Systemic lidocaine inhibits high-mobility group box 1 messenger ribonucleic acid expression and protein in BALB/c mice after closed fracture musculoskeletal injury," Saudi J Anaesth, vol. 12, no. 3, pp.395-298, 2018. DOI: 10.4103/sja.SJA_685_17.

12. T.D. Wahyuni, M. Hatta, A. Bukhari, A. Santoso, M.N. Massi, “Increasing Natural Resistance Associated Macrophage Protein 1 serum level after Miana treatment in BALB/c induced Klebsiella pneumoniae experimental research," Annals of Medicine and Surgery, vol. 65, no 2021, pp.102262, 2021. DOI: 10.1016/j.amsu. 2021.102262.

13. Farsida, S. Rahmini, M. Hatta, I. Patellongi, Prihantono, M.N. Massi, A. A. Islam, R. Natzir, A.D. B. Febriani, F. Hamid, Fatimah, R. Akaputra, P. A. Savitri, "Relationship between expression mRNA gene Treg, Treg, CD4+, and CD8+ protein levels with TST in tuberculosis children: A nested case-control," Annals of Medicine and Surgery, vol. 61, pp 44-47, 2021. DOI: 10.1016/j.amsu.2020.12.011.

14. M.H. Oley, M.C. Oley, D.E. Tjandra, S.W. Sedu, E.R.N. Sumarauw, D.M.R. Aling, M. Hatta, M. Faruk, "Hyperbaric oxygen therapy in the healing process of foot ulcers in diabetic type 2 patients marked by interleukin 6, vascular endothelial growth factor, and PEDIS score: A randomized controlled trial study," International Journal of Surgery Open, vol 27. No. pp. 154-161, 2020. DOI:10.1016/j.ijso.2020.11.012.

15. F. Shamara and M. Fachri, "Karakteristik pasien PPOK stabil dikaitkan dengan kebiasaan merokok berdasarkan nilai indeks brinkman di RS Islam Sukapura," Journal of the Indonesian Medical Association, vol. 64, no. 12, pp. 564-569, 2014.

16. G. L. Brinkmann and E. O. Coates, "The effect of bronchitis, smoking and occupation on ventilation," The American Review of Respiratory Disease, vol. 87, pp. 684-693, 1963.

17. F. Yunus, "Gambaran penderita PPOK yang dirawat di bagian Pulmonologi FKUI/RSUP Persahabatan Jakarta," Jurnal Respirologi Indonesia, vol. 20, pp. 64-68, 2000.

18. Suradi, Y. S. Sutanto, Revino, Harsini, D. Marhendra, “Hubungan antara Penyakit Paru Obstruktif Kronik Eksaserbasi Akut dengan Hasil Kultur Sputum Bakteri pada Rumah Sakit R. Moewardi Surakarta," Jurnal Respirologi Indonesia, vol. 32, no. 4, pp. 218-222, 2012.

19. M. Hatta, A. R. Sultan, N. Tandirogang, Masjudi, Yadi, "Detection and identification of mycobacteria in sputum from suspected tuberculosis patients," BMC Research Notes, vol. 3, pp. 72, 2010. https://doi.org/10.1186/1756-0500-3-72

20. T.A. Wikanningtyas, M. Hatta, M.N. Massi, I. Pratiwi, M. Fachri, U. Bahrun, I. Djaharuddin, N.A. Abdul Kadir, "Hematologic parameters in pulmonary tuberculosis patients based on the microscopic sputum examination”, Enfermería Clínica, vol 30, Suppl 2, p 243-246, 2020. https://doi.org/10.1016/j.enfcli.2019.07.098 
21. M. Fachri, M. Hatta, S. Abadi, S.S. Santoso, T.A. Wikanningtyas, A. Syarifuddin, R. Dwiyanti, R.A. Noviyanthi. "Comparison of Acid Fast Bacilli (AFB) smear for Mycobacterium tuberculosis on adult Pulmonary tuberculosis (TB) patients with type 2 Diabetes Mellitus (DM) and without type 2 DM". Respiratory Medicine and Case Report. Vol 23 (2018): 158-162, 2018. https://doi.org/10.1016/j.rmcr.2018.02.008

22. S. C. Foley, A. K. Mogas, R. Olivenstein et al., "Increased expression of ADAM33 and ADAM8 with disease progression in asthma," The Journal of Allergy and Clinical Immunology, vol. 119, no. 4, pp. 863-871, 2007.

23. I. Ito, J. D. Laporte, P. O. Fiset et al., "Downregulation of a disintegrin and metalloproteinase 33 by IFNgamma in human airway smooth muscle cells," The Journal of Allergy and Clinical Immunology, vol. 119, no. 1, pp. 90-97, 2007.

24. I. Puxeddu, Y. Y. Pang, A. Harvey et al., "The soluble form of a disintegrin and metalloprotease 33 promotes angiogenesis: implications for airway remodeling in asthma," The Journal of Allergy and Clinical Immunology, vol. 121, no. 6, pp. 1400-6.e4, 2008.

\section{Figures}




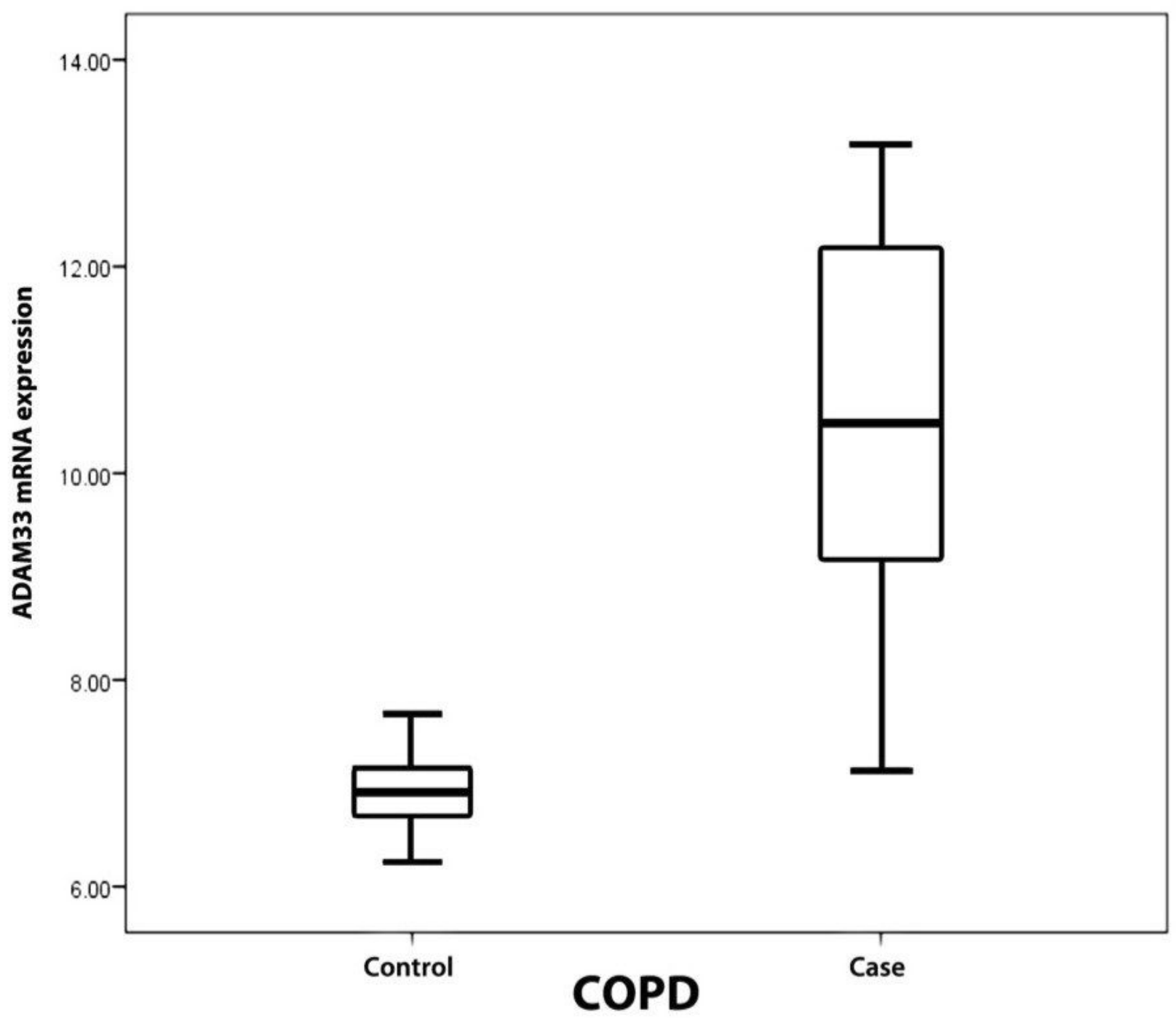

Figure 1

Boxplot for the levels of ADAM33 mRNA in COPD patients and non-COPD individuals. 


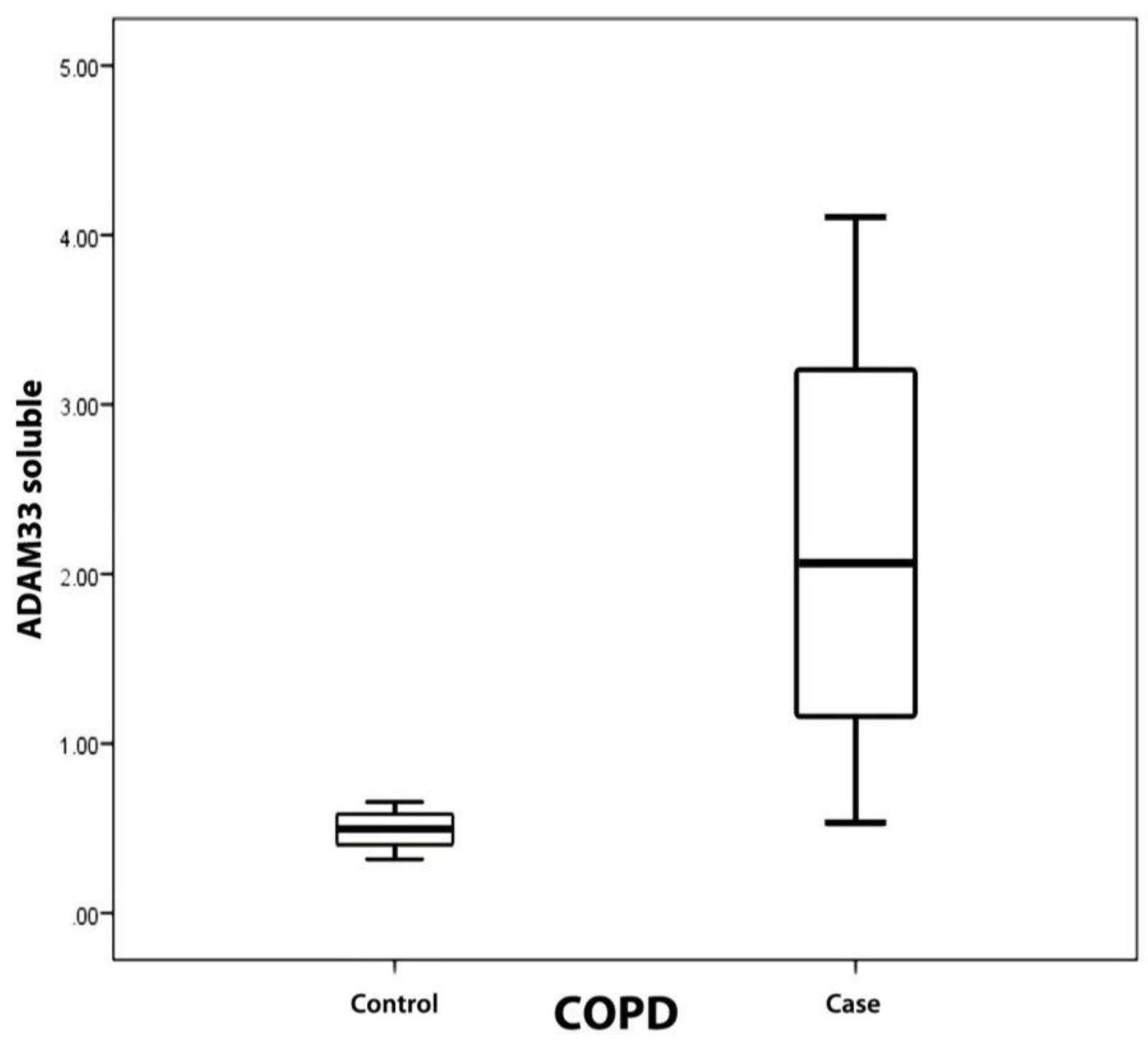

Figure 2

Boxplot for the levels of soluble ADAM33 in COPD patients and non-COPD individuals. 